\title{
Vegetation Cover in Rudat Norah and Morphmetric Analysis of Wadi Al-Atsh Watershed, Northwester Riyadh Region
}

\author{
Rashid H.R. Al-Dosari ${ }^{*}$, A.M. El-Sheikh Al-Ansari', \\ F.H. Al-Juaidi ${ }^{2}$ and W.A. Al-Taisan ${ }^{3}$ \\ ${ }^{1}$ Department of Botany and Microbiology, College of Science, King Saud University, \\ PO Box 2455, Riyadh 11451, Saudi Arabia \\ ${ }^{2}$ Department of Geography, College of Art, King Saud University, Riyadh, Saudi Arabia \\ ${ }^{3}$ Department of Biology, College of Science, Imam Abdulrahman Bin Faisal University, \\ Saudi Arabia \\ *Corresponding author
}

Keywords

Morphometric,

Wadi Al-Atsh,

Watershed,

Drainage, Saudi

Arabia

Article Info

Accepted:

04 February 2019

Available Online:

10 March 2019

\begin{abstract}
A B S T R A C T
Vegetation Cover in Rawdat Norah was estimated to be $0.635 \mathrm{Km}^{2}$ or $16.2 \%$ of the total area of the Rawdat which is $3.924 \mathrm{~km}^{2}$. The main dominant vegetation is Rhazya strica. Some morphometric properties and the characteristics of the watercourse system affecting the capacity of the Wadi Al-Atsh watershed to transform rainwater into surface runoff water had been determined. Accordingly, the drainage area of Wadi Al-Atsh has been calculated and found to be $13899.7 \mathrm{~km}^{2}$, where the watershed length reaches $170.9 \mathrm{~km}$, and the average width of Wadi Al-Atash watershed also reached $81.3 \mathrm{~km}$. The form factor ratio was found to be less than 1.277 indicating that the shape of the watershed is not circular in shape, the shape of Wadi Al-Atsh watershed is located within the relatively rectangular watersheds where its elongation reaches 0.78 . This study also proven that the watercourse network system is similar to the dendritic drainage system with a total of 1759 watercourses, which confirms the ability of the water watershed to turn the rainwater into surface running water which may end with devastating foods. This study indicated that management of rangeland must incorporate to conserve vegetation and biodiversity of ephemeral streams in hvper-arid and arid regions.
\end{abstract}

\section{Introduction}

In arid regions, patterns of vegetation are influenced by human disturbance such as overgrazing and environmental factors mainly climate and topography characteristics (Jiao et al., 2011). Thus morphometric parameters analysis of watershed is an important aspect (Ali et al., 2000; Al-Rowaily et al., 2012). Shaw and Cooper (2008) noted that plant communities and other biotic patterns are controlled by the interactions of hydrologic and geomorphic regimes. The hydrological response in a basin is a result of the physiographic characteristics, such as area, slope, size and length of streams, size, shape, slope, and drainage density (Gregory and Walling, 1973). In hyper-arid and arid regions, many studies demonstrated that quantitative morphometric analysis has, 
prioritization for soil and water conservation (Gajbhiye et al., 2014; Meshram and Sharma 2015), environmental assessment (Magesh et al., 2012; Rai et al., 2014; Babu et al., 2016), and evaluation and management of resources (Pandey et al., 2004). Furthermore, comparison of the quantitative morphometric parameters helps understand the geomorphological effects on the spatial variation of hydrological functions (Romshoo et al., 2012; Sreedevi et al., 2013). Understanding drainage morphometry is also a prerequisite for runoff modeling, geotechnical investigation, identification of water recharge sites and groundwater prospect mapping (Sreedevi et al., 2005; Fenta et al., 2015; Roy and Sahu 2016). As such, morphometric analysis is an important procedure for quantitative description of the drainage system; thus enabling improved understanding and better characterization of $s$.

This study aims were to estimate vegetation cover in Rawdat Norah and some of the morphometric characteristics associated with Wadi Al-Atsh watershed.

\section{Materials and Methods}

\section{The study area}

Wadi Al-Atsh is located between the two longitude $45^{\circ} 00$ and $46^{\circ} 20^{\prime}$ east, $24^{\circ} 20^{\prime}$ and $25^{\circ} 58^{\prime}$ north (Fig. 1). It is bordered by the edges of Tuwaiq Escarpment in the south, and by Wadi al-Nakhl watershed from the Northwest. Al-Qassap salted area is bordering Wadi Al-Atsh from the southwest side, while Al-Shawki valley from the north, and finally from the east is bordered by the lowlands of Rawdat Norah.

Wadi Al-Atsh stream is formed after the confluence of the water valley with the valley of Sidair at an altitude of about 590m near the Rawdat Quabaa. The Geological and relief characteristics of the Wadi Al-Atsh watershed are part of the sedimentary Arabian shelf structures. These structures vary in terms of age, geological structure and rock composition.

\section{Vegetation and morphometric measurements}

Vegetation cover was measured using GIS following Sharaf (2008) method using a satellite image, (Spot-6), with a resolution of 1.3. Vegetation (NDVI) was estimated from the image. A number of morphometric parameters such as area, elevation information, watershed length, and number and length of stream were computed. The area and shape of the drainage watershed had been calculated (length, width, and circumference). Stream order was carried out based on Strahler (1964) method.

The elongation ratio was calculated according to (Schumm, 1956). The elongation ratio value is calculated by applying the following equation:

Where:

$\mathbf{R}_{\mathrm{e}}=\left\lfloor\frac{2}{\mathbf{L}_{\mathbf{b}}}\right\rfloor\left\lceil\frac{\mathrm{A}}{\pi}\right\rfloor^{0.5}$

A: Watershed water drainage area $\left(\mathrm{km}^{2}\right)$. $\mathrm{L}_{\mathrm{b}}$ : Length of water watershed $(\mathrm{km})$.

The Relative relief ratio was calculated according to (Melton, 1957) using the equation:

Where:

$\mathrm{H}$ : The relief range which is the difference between the maximum and the $\mathrm{R}_{\mathrm{hp}}=\frac{1000 \mathrm{H}}{\mathrm{P}}$ lowest height in the water watershed (meters).

P: Length of water watershed circumference (km). 
The Drainage intensity was calculated according to Faniran, (1968), using the equation:

$D i=F s / D d$

Where:

$\mathrm{F}_{\mathrm{s}}$ : Frequency of watercourses $\left(\right.$ stream $\left./ \mathrm{km}^{2}\right)$.

$\mathrm{D}_{\mathrm{d}}$ :Density of watercourses $\left(\mathrm{Km} / \mathrm{Km}^{2}\right)$.

\section{Results and Discussion}

From satellite image, area of Rawdat Norah was estimated to be $3.924 \mathrm{~km}^{2}$. Vegetation Cover in Rawdat Norah was estimated to be $0.635 \mathrm{Km}^{2}$ or $16.2 \%$ (Figures 2). The main dominant vegetation is Rhazya strica.

The results of this study revealed that the maximum elevation of Wadi Al-Atsh watershed was $1001 \mathrm{~m}$ at the edge of Tuwaiq
Mountain in the southwest of the drainage area, and the minimum elevation of the watershed was $541 \mathrm{~m}$ at the outlet of the watershed in the lowlands of Rawdat Noura (Figure 3).

Wadi Al-Atsh watershed area was estimated to be $13899.7 \mathrm{~km}^{2}$. Some of the watershed shape characteristics which govern the rate at which water is supplied to the main channel also estimated basin length $(170.9 \mathrm{~km})$; main basin width $(81.3 \mathrm{~km})$, form factor ratio $(0.48)$, elongation ratio $(0.78)$, circularity ratio (0.41), and compactness coefficient (1.57) (Table 1).

The total stream was 1759 with total length of $7154.5 \mathrm{~km}$. The first order streams make about $76.86 \%$ of the total number and $50.53 \%$ of the total length (Table 2 and Figure 4).

Table.1 Morphometric parameters of Wadi Al-atsh northwest of Riyadh Region

\begin{tabular}{|c|c|c|c|c|c|c|c|c|}
\hline $\begin{array}{c}\text { Watershed } \\
\text { derange } \\
\left.\text { Area } \mathbf{( k m}^{\mathbf{2}}\right)\end{array}$ & $\begin{array}{c}\text { Peri- } \\
\text { meter } \\
\mathbf{( k m )}\end{array}$ & $\begin{array}{c}\text { Water- } \\
\text { shed } \\
\text { length } \\
\mathbf{( k m )}\end{array}$ & $\begin{array}{c}\text { Mean } \\
\text { water-shed } \\
\text { width } \mathbf{( k m )}\end{array}$ & $\begin{array}{c}\text { Form } \\
\text { factor } \\
\text { ratio }\end{array}$ & $\begin{array}{c}\text { Elongation } \\
\text { ratio }\end{array}$ & $\begin{array}{c}\text { Circulari } \\
\text { ty ratio }\end{array}$ & $\begin{array}{c}\text { Compactness } \\
\text { coefficient }\end{array}$ & $\begin{array}{c}\text { Lemniscate } \\
\text { factor }\end{array}$ \\
\hline $\mathbf{1 3 8 9 9 . 7}$ & 652.7 & 170.9 & 81.3 & 0.48 & 0.78 & 0.41 & 1.57 & 0.02 \\
\hline
\end{tabular}

Table.2 Stream order, number of streams, stream length, mean stream length, of Wadi Al-atsh northwest of Riyadh Region

\begin{tabular}{|c|c|c|c|c|c|}
\hline $\begin{array}{c}\text { Stream } \\
\text { order }\end{array}$ & $\begin{array}{c}\text { No. of } \\
\text { stream }\end{array}$ & $\%$ & $\begin{array}{c}\text { Bifurcation } \\
\text { ratio }\end{array}$ & $\begin{array}{c}\text { Total stream } \\
\text { length } \mathbf{( K m})\end{array}$ & $\begin{array}{c}\text { Mean stream } \\
\text { length }(\mathbf{K m})\end{array}$ \\
\hline $\mathbf{1}^{\text {st }}$ & 1352 & 76.86 & ---- & 3614.9 & 2.67 \\
\hline $\mathbf{2}^{\text {nd }}$ & 316 & 17.96 & 4.28 & 1798.8 & 5.69 \\
\hline $\mathbf{3}^{\text {rd }}$ & 66 & 3.75 & 4.79 & 923.2 & 13.99 \\
\hline $\mathbf{4}^{\text {th }}$ & 19 & 1.08 & 3.47 & 525.4 & 27.65 \\
\hline $\mathbf{5}^{\text {th }}$ & 5 & 0.28 & 3.80 & 226.2 & 45.25 \\
\hline $\mathbf{6}^{\text {th }}$ & 1 & 0.06 & 5.00 & 66.0 & 65.98 \\
\hline Total/mean & 1759 & 100 & 4.27 & 7154.5 & 4.07 \\
\hline
\end{tabular}


Fig.1 Al-Atsh watershed location in Saudi Arabia

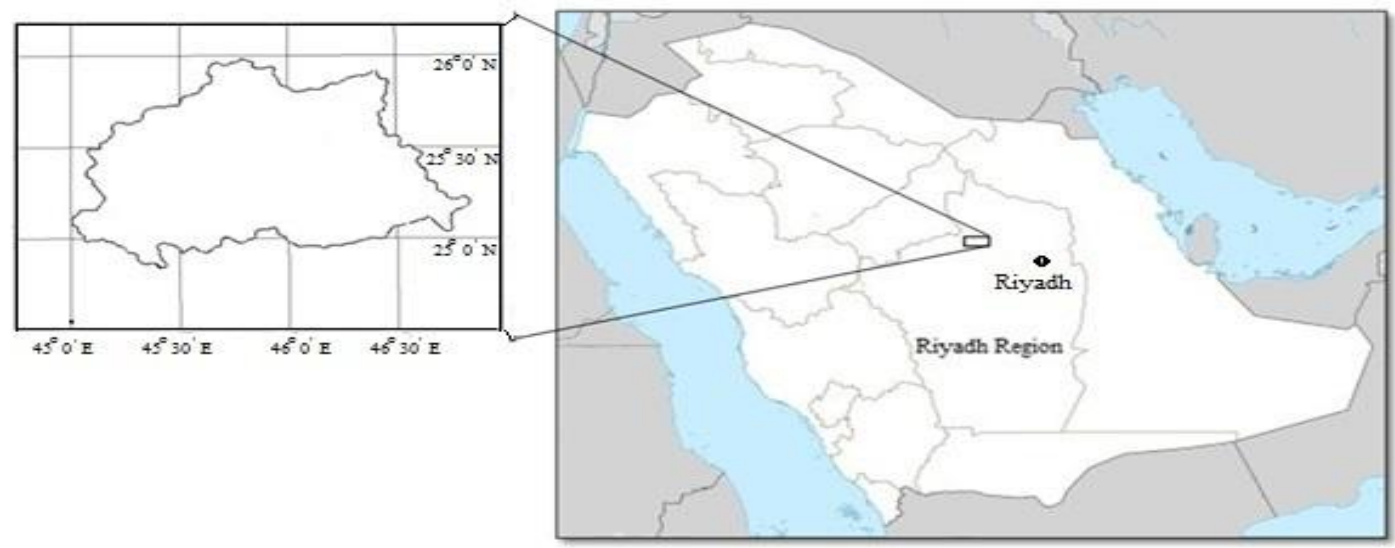

Fig.2 Satellite image showing Rawdat Norah location and vegetation cove

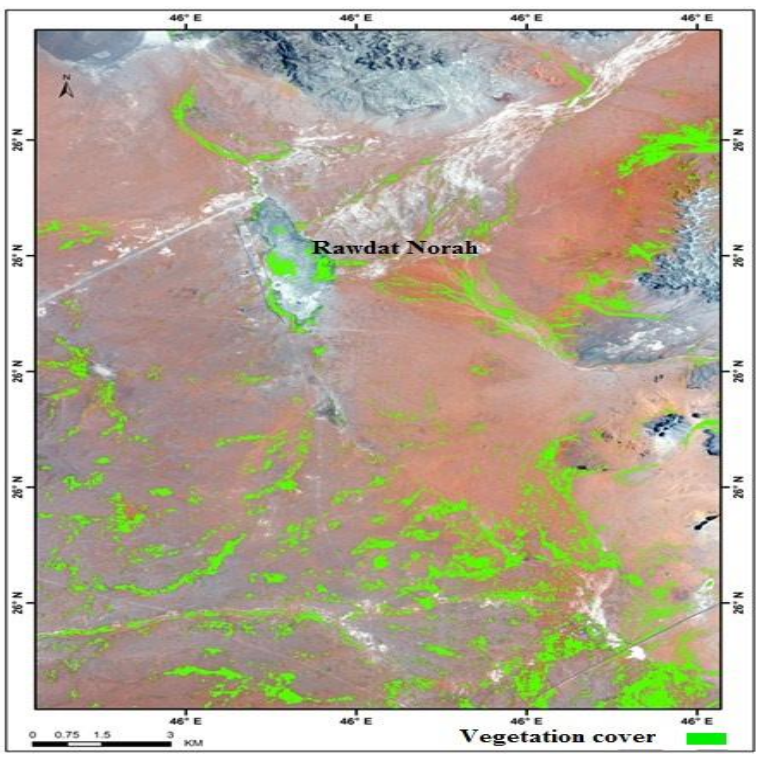

Fig.3 Elevation map of Wadi Al-Atsh watershed

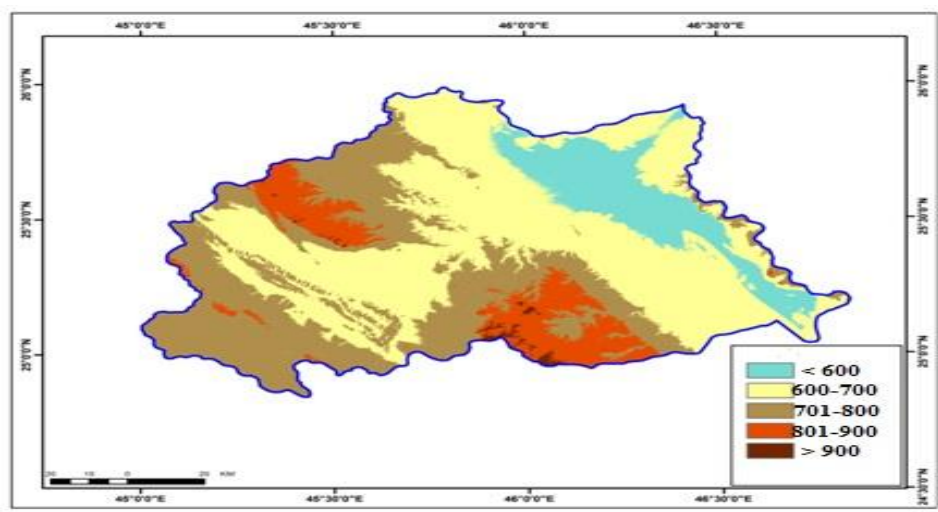


Fig.4 Hierarchical of stream orders of Wadi Al - Atsh Watershed (ranked according to Strahler 1964)

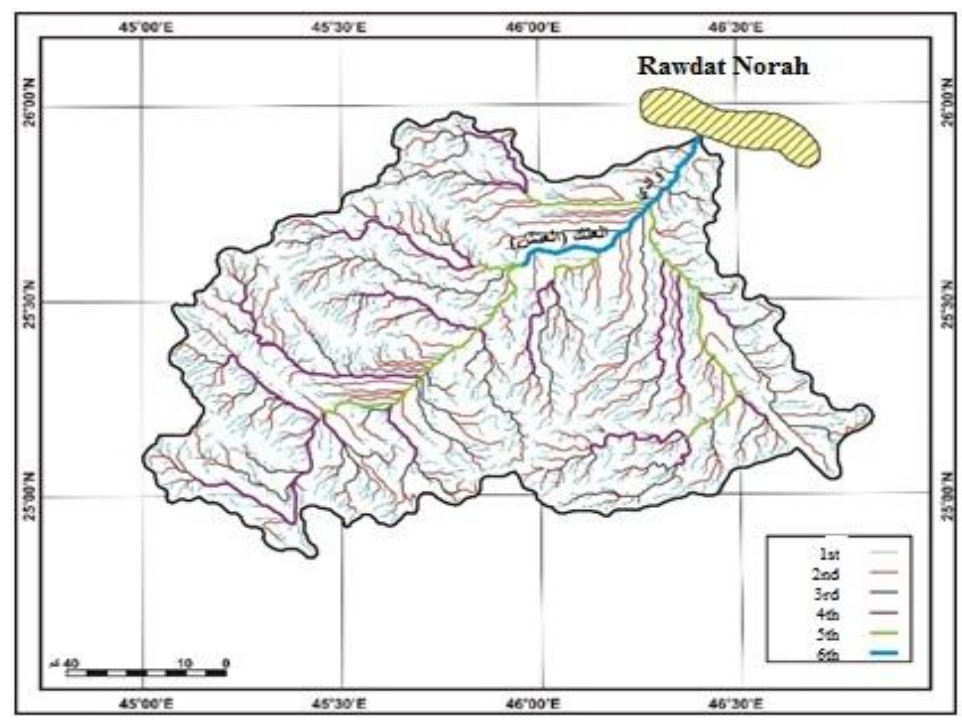

Vegetation cover of Rawdat Norah was low because of human disturbance such as overgrazing and environmental factors mainly climate and topography (Jiao et al., 2011; Xu et al., 2008). Determination of stream networks' behavior and their interrelation with each other is of great importance in arid and semiarid ecosystems because watershed area is considered the source that supplies water needs (Leopold et al., 1964). Wadi AlAtsh watershed is well drained with stream order of six. This hierarchical arrangement of watercourses determines surface runoff water and the development of the waterway in the watershed. The watercourse network system in Wadi Al-Atsh is similar to the dendritic drainage system (Fig 4) with a total of 1759 watercourses, that confirms the ability of the water watershed to turn the rainwater into surface running water.

The presence of large number of streams in Wadi Al-Atsh watershed (1759) indicates that the topography is still undergoing erosion and at the same time, less number of streams indicates mature topography. The calculated result matched with Strahler (1964), that the total number of streams decreases gradually as the stream order increases. High values of first-order streams may indicate a possibility of flash floods after heavy rainfall in the down streams (Chitra et al., 2011). From the parameters obtained, the average slope of Wadi Al-Atsh watershed is $2.67 \mathrm{~m} / \mathrm{km}$, which considered as high, and the high relief value of the watershed indicates the gravity of water flow, low infiltration and high runoff conditions. Magesh et al., (2012) noted similar observations in Tamiraparani subwatershed because the presence of Western Ghats acts as a common relief-contributing factor. The Drainage Intensity (DI) of Wadi Al-Atsh watershed is 0.25 watercourse $/ \mathrm{km}^{2}$ which indicates that the watershed has a weak or permeable subsurface material with intermediate drainage and low relief (Chorley 1969).

The present study has proved that analysis of some morphometric parameters of a watershed also can helps to understand vegetation. Degradation of vegetation resources of Rawdat Norah as a result of human disturbance mainly heavy grazing, 
resulted in low vegetation cover, low productivity, low plant diversity, and the replacement of palatable species by unpalatable Rhazya strica. Thus, rangeland management practices must incorporate to conserve biodiversity of ephemeral streams in hyper-arid and arid regions (Sarr, 2002).

\section{References}

Ali M. M., Dickinson G., and Murphy K. J., (2000). Predictors of plant diversity in a hyper-arid desert wadi ecosystem. Journal of Arid Environments 45:215230

Al-Rowaily S.L., Magdy I. El-Bana, and Fahad A.R. Al-Dujain (2012). Changes in vegetation composition and diversity in relation to morphometry, soil and grazing on a hyper-arid watershed in the central Saudi Arabia. Catena, 97:41-49

Babu K J, Sreekumar S, Aslam A (2016) Implication of drainage basin parameters of a tropical river basin of South 547 India. Appl Water Sci 6: $67-75$

Chitra C., Alaguraja P., Ganeshkumari K., Yuvaraj D., and Manivel M. (2011). Characteristics of Kundahsub watershed using remote sensing and GIS techniques. Int. J. Geomatics Geosci. 2(1):311-335

Chorley R.J. (1969). Introduction to physical hydrology. Methuen and Co. Ltd., Suffolk, p 211

Faniran, A. (1968). The index of drainage intensity: A provisional new drainage factor. Australian Journal of Science 31:328-330.

Fenta A.A., Kifle A., Gebreyohannes T., and Hailu G. (2015). Spatial analysis of groundwater potential using remote sensing and GIS-based multi-criteria evaluation in Raya Valley, northern Ethiopia. Hydrogeology J. 23(1): 195-
206

Gajbhiye S., Mishra S.K., Pandey A. (2014). Prioritizing erosion prone area through morphometric analysis: an RS and GIS perspective. Appl Water Sci. 4(1): 51-61

Gregory K.J., Walling D.E. (1973). Drainage basin form and process: a geomorphological approach. Willey, the University of Michigan

Jiao F., Wen Z., and An S., (2011). Changes in soil properties across a chronosequence of vegetation restoration on the Loess Plateau of China. Catena 86:110-116.

Leopold, L. B., Wolaman, M. G. and Miller, J. P. (1964). Fluvial Process in Geomorphology, Freeman \& Co., London.

Magesh N.S., Chandrasekar N., and Kaliraj S. (2012). A GIS based automated extraction tool for the analysis of basin morphometry. Bonfring Int. J. Indus Eng. Manag. Sci. 2(1):32-35.

Melton, M.A. (1957). An Analysis of the relations among elements of climate, Surface properties and geomorphology, Project NR 389042, Tech. Rep. 11, Columbia University.

Pike, R. J, and Wilson, S.E. (1971): Elevation-relief ratio: hypsometric integral and geomorphic area-altitude analysis, Geol. Soci. Amer. Bull. 82:1079-1084.

Meshram S.G., Sharma S.K. (2017). Prioritization of watershed through morphometric parameters: a PCAbased approach. Appl Water Sci. 7(3):1505-1519.

Pandey A., Chowdary V.M., Mal B.C. (2004). Morphological analysis and watershed management using geographical information system. J. Hydro 127(34):71-84

Rai P.K., Mohan K., Mishra S., Ahmad A., Mishra V.N. (2014). A GIS-based 
approach in drainage morphometric analysis of Kanhar River Basin, India. Appl Water Sci. 7(1):217-232.

Romshoo S.A., Bhat S.A., Rashid I. (2012). Geoinformatics for assessing the morphometric control on hydrological response at watershed scale in the upper Indus basin. J. Earth Syst Sci 121(3):659-686

Roy S., Sahu A.S. (2016). Effectiveness of basin morphometry, remote sensing and applied geosciences on groundwater recharge potential mapping: a comparative study within a small watershed. Front Earth Sci 10(2): 274-627 291

Schumm, S.A. (1956). Evolution of drainage systems and slopes in Badlands at Perth Amboy, New Jersey. Geol. Soci. Amer. Bull. 67:597-646.

Sreedevi P.D., Subrahmanyam K., Ahmed S. (2005). The significance of morphometric analysis for obtaining groundwater potential zones in a structurally controlled terrain. Environ Geol 47: 412-420

Sreedevi P.D., Sreekanth P.D., Khan H.H., Ahmed S. (2013). Drainage morphometry and its influence on hydrology in an semi-arid region: using SRTM data and GIS. Environ Earth Sci 70(2): 839-848

Sarr D.A. (2002). Riparian livestock exclosure research in the western United States: a critique and some recommendations. Environmental Management 30:516-526.

Strahler, A. N. (1964). Quantitative geomorphology of drainage watersheds and channel networks, In V.T. Chow (ed.), Handbook of Applied Hydrology, 4-39/4-76

Xu X.L., Ma K.M., Fu B.J., Song C.J., and Liu W. (2008). Relationships between vegetation and soil and topography in a dry warm river valley, SW China. Catena 75:138-145.

\section{How to cite this article:}

Rashid H.R. Al-Dosari, A.M. El-Sheikh Al-Ansari, F.H. Al-Juaidi and Al-Taisan, W.A. 2019. Vegetation Cover in Rudat Norah and Morphmetric Analysis of Wadi Al-Atsh Watershed, Northwester Riyadh Region. Int.J.Curr.Microbiol.App.Sci. 8(03): 188-194.

doi: https://doi.org/10.20546/ijcmas.2019.803.026 